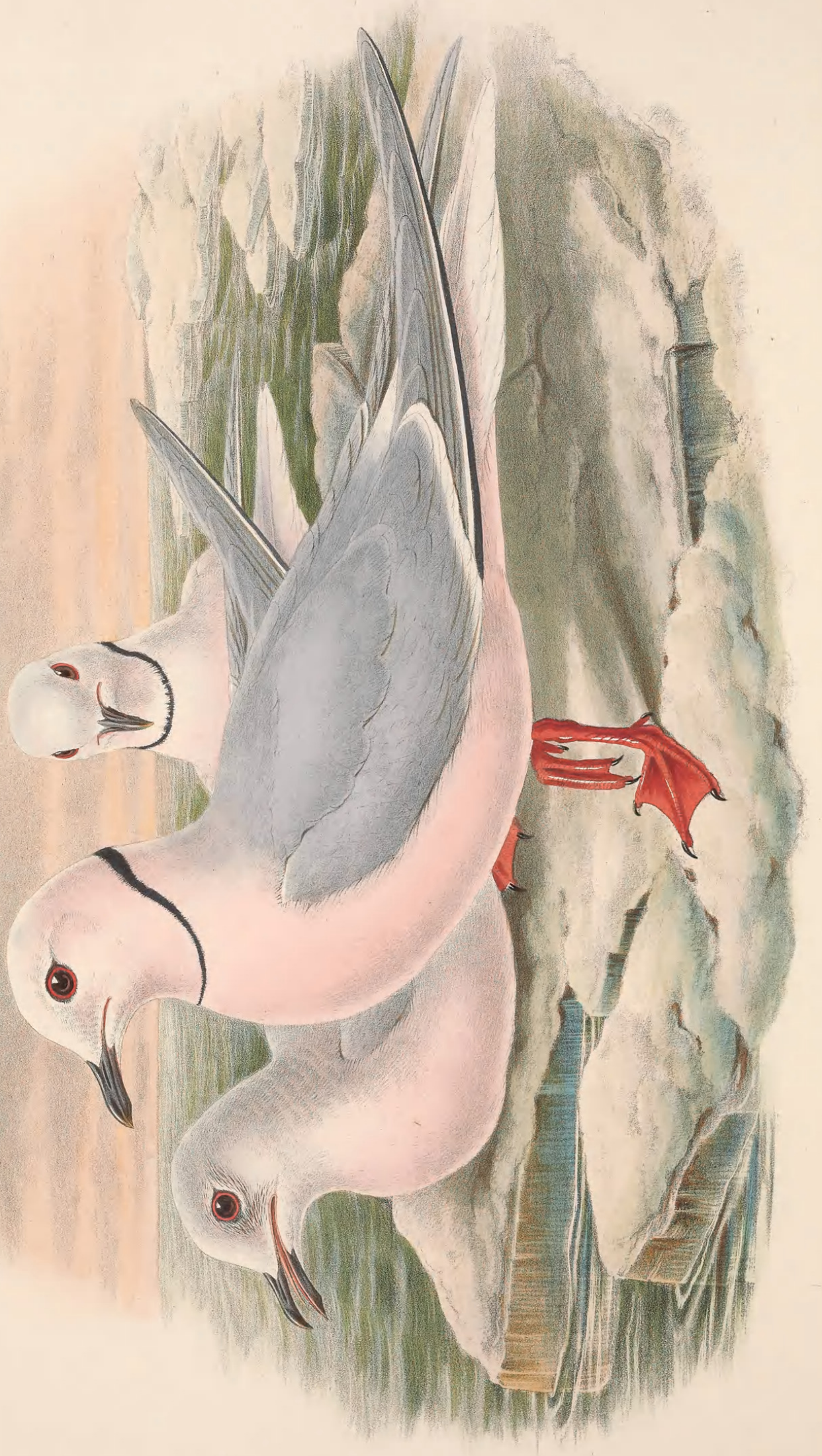




\title{
RHODOSTE'THIA ROSSII.
}

\author{
Ross's Gull.
}

Larus roseus, Jard. \& Selby, Ill. Orn., vol. i. pl. 14.

Rossii, Rich. Parry's Second Voy., App., p. 359.

Rossia rosea, Bonap. Geog. and Comp. List of Birds of Eur. and N. Amer., p. 62.

Rhodostethia Rossii, Macgill. Man. of Nat. Hist. Orn., vol. ii. p. 252.

rosea, Baird, Cat. of N.-Amer. Birds in Mus. Smithsonian Inst., no. 678.

THIs small and beautifully coloured Gull has a just claim to a place in the avifauna of Britain, from the circumstance of an individual having been killed in Yorkshire-and in that of continental Europe, from another example having been shot in Heligoland. The native home of the species is, doubtless, the high northern regions of the Old World, Commander James Clark Ross having killed it on the coast of Melville Peninsula, and several more having been seen as far towards the poles as our intrepid navigators have yet penetrated, beyond which little is known respecting this the rarest species of the Larina. To these few brief sentences I subjoin the scanty information that has been recorded, and would recommend any one who may hereafter voyage towards the north pole to distinguish himself by observing and communicating to the world all he can respecting its habits and economy.

Sir John Richardson says (in the 'Fauna Boreali-Americana,' Part ii. The Birds) :- " Two specimens of this Gull were killed on the coast of Melville Peninsula, on Sir Edward Parry's voyage, one of which is preserved in the Museum of the University of Edinburgh, and the other was presented to Joseph Sabine, Esq. No other examples are known to exist in collections; but Commander Ross, in his Zoological Appendix to Sir Edward Parry's Narrative of his most adventurous boat-voyage towards the pole, relates that several were seen during their journey over the ice north of Spitzbergen, and that Lieutenant Forster also found the species in Waygate Straits, which is probably one of its breeding-places. It is to Commander Ross, who killed the first specimen which was obtained, that the species is dedicated, as a tribute for his unwearied exertions in the promotion of natural history on the late Arctic voyages, in all of which he bore a part. Of the peculiar habits or winter retreat of the species nothing is known." Of the two specimens above mentioned, the one presented to the Museum of the Edinburgh University is still extant ; and I have to record my obligations to Professor Archer and the other authorities of that Museum, for their kindness in permitting their valuable specimen to be forwarded to London for my use in the present work; the whereabouts of the other, presented to Mr. Sabine, cannot, after a diligent investigation, be ascertained ; it is just possible that it may be the example in the Derby Museum, at Liverjool, which was also kindly sent up for my use.

"For the knowledge of the occurrence of this very rare Gull in Yorkshire," says Yarrell, " and its consequent title to be included in a history of British birds, we are indebted to $\mathrm{Mr}$. Charlesworth, who, in a paper published in the first volume of the 'Proceedings of the Yorkshire Philosophical Society,' gave all that was known respecting it. The capture is anthenticated by the following memorandum, supplied by Sir William Milner, of Nun Appleton:- 'Ross's Gull was killed by Horner, Lord Howden's head gamekeeper, in February 1847, in a ploughed field, near the hamlet of Milford-cum-Kirby, in the parish of Kirby. Its flight resembled, according to Horner's account, the flight of any other Gull ; and it did not seem at all shy.' Mr. William Macgillivray includes this bird in his 'Manual of British Birds,' vol. ii. p. 254, published in 1842, with the remark that 'this species has once occurred in Ireland.' I remember to have seen, some years ago, a notice in print that this bird had been once taken in Ireland; but, from the countries visited or known to the writer of that article, and from the circumstance that this species had only been seen in high northern latitudes, I came to the conclusion that the printer had made a mistake of one letter, and for Ireland we ought to read Iceland. Add to this that the birds of Ireland have been carefully worked out by Mr. Thompson, of Belfast, one of the best authorities for Irish birds, and this species is not included by him in his fauna of that country. I may also add that Ross's Gull has no place in Mr. Watter's useful 'Manual of the Birds of Ireland,' published in Dublin in 1853.”

Sir John Richardson's description " of a specimen killed, June 1823, at Alagnak, Melville Peninsula, $69 \frac{1}{4}^{\circ} \mathrm{N} ., "$ is as follows :-

"CoLour.-Scapulars, interscapulars, and both surfaces of the wings clear pearl-grey; outer web of the first quill blackish brown to its tip, which is grey; tips of the scapulars and lesser quills whitish. Some 
small feathers near the eye, and a collar round the middle of the neck pitch-black. Rest of the plumage white; the neck above, and the whole under plumage deeply tinged with peach-blossom-red in recent specimens. Bill black; its rictus and the edges of the eyelids reddish orange. Legs and feet vermilion red; nails blackish.

"Fonm.-Bill slender, weak, with a scarcely perceptible salient angle beneath; the upper mandible slightly arched, and compressed towards the point; the commissure slightly curved at the tip. Wings an inch longer than the decidedly cuneiform tail, of which the central feathers are an inch longer than the outer ones. Tarsi rather stout; the thumb very distinct, armed with a nail as large as that of the outer toe.

"The other specimen, killed by $\mathrm{Mr}$. Sherer a few days later, differs only in the first primary coverts having. the same dark colour with the outer web of the first primary itself."

The Yorkshire specimen, which is now in Sir William Milner's collection, is similar in colouring to the above, but is destitute of the black colour around the neck, whence we may infer that it is in the winter plumage.

Yarrell gives the following measurements:- "The whole length of the bird is about fourteen inches; wing, from the anterior bend to the end of the first primary, which is the longest, an inch and a half; bill, from the point to the feathers on the top, three fourths of an inch; length of the tarsus one inch and a quarter."

The figures, which are of the natural size, represent two birds in summer dress and one in that of winter, drawn from the example at Nun Appleton. 


\section{$2 \mathrm{BHL}$ Biodiversity Heritage Library}

Gould, John. 1873. "Ross's Gull, Rhodostethia rossii [PI. 63]." The birds of Great Britain 5, -. https://doi.org/10.5962/p.324107.

View This Item Online: https://www.biodiversitylibrary.org/item/222497

DOI: https://doi.org/10.5962/p.324107

Permalink: https://www.biodiversitylibrary.org/partpdf/324107

\section{Holding Institution}

Smithsonian Libraries

\section{Sponsored by}

Biodiversity Heritage Library

\section{Copyright \& Reuse}

Copyright Status: Public domain. The BHL considers that this work is no longer under copyright protection.

This document was created from content at the Biodiversity Heritage Library, the world's largest open access digital library for biodiversity literature and archives. Visit BHL at https://www.biodiversitylibrary.org. 